\title{
Composting of Calotropis gigantea Leaves In Presence of Sheep Dung
}

\author{
MAYUR C. SHAH ${ }^{\star 1}$, JALDIP C. KANSARA ${ }^{1}$ and PRATEEK G. SHILPKAR ${ }^{2}$ \\ 1'Department of Microbiology, Gujarat Vidyapith, Sadra, District Gandhinagar, Gujarat-382 320, India. \\ ${ }^{2}$ Biogas Research and Extension Centre, Gujarat Vidyapith, Sadra, District Gandhinagar, \\ Gujarat-382 320, India.
}

http://dx.doi.org/10.12944/CWE.10.1.34

(Received: January 28, 2015; Accepted: February 23, 2015)

\begin{abstract}
Calotropis gigantea is a plant grown almost everywhere and has no economic use. Leaves of Calotropis gigantea plants were composted with sheep dung. Composting conditions were maintained and samples were withdrawn at 30,60 and 90 days of composting and analysed for $\mathrm{pH}$, electrical conductivity, $\mathrm{Ca}^{2+}, \mathrm{Mg}^{2+}, \mathrm{Cl}^{1-}$, total organic carbon, total nitrogen, available phosphorus and available potassium. Results show that contents of these parameters changes with time and at 90 days nutrient rich compost is obtained with decreased concentration of chloride.
\end{abstract}

Key words: Microbial decomposition, plant wastes, compost, nutrients.

\section{INTRODUCTION}

To feed the ever-increasing human population we have to increase agricultural production using more concentrated forms of plant nutrients as chemical fertilizers but some adverse effects of chemical fertilizers on soil health and environment are also reported like application of ammonium sulfate produces acidic conditions (due to sulfuric acid), reaction of ammonia (produced from urea) with water produce alkaline $(\mathrm{pH} 11.0)$ ammonium hydroxide, both the situations kills microorganisms, seeds and seedlings. Chemical fertilizer contains heavy metals and radionuclides of uranium, thorium and polonium in large amount ${ }^{1,2}$ and their continuous use result in accumulation of heavy metals and radionuclides in soil. The safe way to save the natural ecology of soil is to adopt integrated nutrient management technique which includes application of both, organic and inorganic fertilizers. Organic fertilizers are slow release fertilizers and releases nutrients as per the need of crop plants so there is no chance of nutrients leaching or evaporation.
Besides this organic fertilizers contains almost all the essential plant nutrients whereas chemical fertilizers contain only major nutrients. Proper plant growth and hence better yield requires supply of all the required nutrients. Compost is one form of organic fertilizers produced by microbial degradation of a number of degradable organic wastes through activities of aerobic microorganisms in moist environment. Application of compost promote plant growth ${ }^{3-5}$ and it may be a part of integrated nutrient management ${ }^{6}$. Composting requires presence of microorganisms for degrading the waste material used for it. The main source of microorganisms is dung. Sheep are small ruminant animals of Family- Bovidae and Subfamily- Caprinae. They are reared in many parts of world for wool and mutton. The population of sheep in India in the year 2012 is 65.06 million. Calotropis gigantea is a medicinal plant grown on variety of soil types but it contains poisonous milky juice so it is not used for grazing or other means. Present study aimed to prepare compost using leaves of Calotropis gigantea and sheep manure. 


\section{MATERIALS AND METHODS}

\section{Composting}

Leaves of Calotropis gigantea and sheep dung were collected locally and put in a $2 \times 2$ feet sized above ground pit prepared using bricks under shade. A sample of sheep dung was kept aside for analysis before mixing it with leaves of Calotropis gigantea. The mixture of dung and leaves was sprinkled with water and mixed well. Putting of dung and leaves in pit was count as zero day of composting (DOC). Now the mixture was left untouched for next six days. On seventh day the mixture was opened, moist with water, mixed well and again put in pit as a heap. This process is called turning and it was given at every seven day interval upto $90 \mathrm{DOC}$. Till $90 \mathrm{DOC}$ only watering and turnings were given, no other activities were done with composting material.

\section{Analysis}

Composting samples were withdrawn from pit at $0,30,60$ and $90 \mathrm{DOC}$ and analysed for $\mathrm{pH}(\mathrm{pH}$ meter), electrical conductivity (conductivity meter), calcium, magnesium and chloride ${ }^{7}$, total organic carbon $^{8}$, total nitrogen ${ }^{9}$, available phosphorus ${ }^{10}$ and available potassium ${ }^{11}$. The zero day sample was analysed only for $\mathrm{C}: \mathrm{N}$ ratio. Sheep dung sample before composting was also analysed for above stated parameters and contains $\mathrm{pH}$ (8.49), electrical conductivity $(1.05 \mathrm{mS} / \mathrm{cm}), \mathrm{Ca}^{2+}(0.033 \%), \mathrm{Mg}^{2+}$ (0.02\%), $\mathrm{Cl}^{1-}(0.11 \%)$, total organic carbon $(17.17 \%)$, total nitrogen (0.56\%), available phosphorus (229.6 $\mathrm{kg} / \mathrm{ha}$ ) and available potassium $(224.0 \mathrm{~kg} / \mathrm{ha})$.

\section{RESULTS AND DISCUSSION}

\section{Physico-chemical parameters}

The $\mathrm{pH}$ of sheep dung alone before composting was 8.49 and after its composting with leaves of Calotropis gigantea for 90 days, it remains 8.50 which shows that composting does not affect $\mathrm{pH}$ and it remains alkaline throughout the composting process (Table-1). On the other hand a sharp decrease in values of electrical conductivity was observed. Data presented in Table-1 show that the electrical conductivity of composting material decreased by $52.38,31.43$ and $79.05 \%$ compared to that of sheep dung before composting after 30 , 60 and 90 days of composting. A fluctuation in contents of calcium, magnesium and chloride ions was observed before and after composting. Before composting the value of calcium, magnesium and chloride ions in sheep dung were 0.033, 0.02 and $0.11 \%$ which fluctuates to $0.024,0.046$ and $0.041 \%$ after composting (Table-1).

Alkaline $\mathrm{pH}$ of compost is due to ammonification. Change in $\mathrm{pH}$ during composting

Table 1: Physico- chemical parameters of composting material at different days of composting

\begin{tabular}{lccccc}
\hline $\begin{array}{l}\text { Days of } \\
\text { composting }\end{array}$ & pH & $\mathrm{EC} \mathrm{(mS/cm)}$ & $\mathrm{Ca}^{2+}(\%)$ & $\mathbf{M g}^{2+}(\%)$ & $\mathrm{Cl}^{1-}(\%)$ \\
\hline 30 & 8.35 & 0.50 & 0.016 & 0.017 & 0.030 \\
60 & 8.19 & 0.72 & 0.024 & 0.046 & 0.030 \\
90 & 8.50 & 0.22 & 0.024 & 0.046 & 0.041 \\
\hline
\end{tabular}

Table 2: Available nutrients at different days of composting ( $\mathrm{kg} / \mathrm{ha})$

\begin{tabular}{lcc}
\hline $\begin{array}{l}\text { Days of } \\
\text { composting }\end{array}$ & $\begin{array}{c}\text { Phosphorus } \\
\left(\mathbf{P}_{2} \mathbf{O}_{5}\right)\end{array}$ & $\begin{array}{c}\text { Potassium } \\
\left(\mathrm{K}_{2} \mathbf{O}\right)\end{array}$ \\
\hline 30 & 128.8 & 537.6 \\
60 & 235.2 & 492.8 \\
90 & 308.0 & 604.8 \\
\hline
\end{tabular}

Table 3: Total organic carbon, total nitrogen and their ratio in composting material at different days of composting

\begin{tabular}{lccc}
\hline $\begin{array}{l}\text { Days of } \\
\text { composting }\end{array}$ & TOC (\%) & Total N (\%) & C:N \\
\hline 30 & 12.55 & 0.41 & 25.10 \\
60 & 8.9 & 0.42 & 21.19 \\
90 & 7.15 & 0.44 & 16.25 \\
\hline
\end{tabular}


Table 4: Changes in $\mathrm{C}: \mathrm{N}$ ratio with composting time

\begin{tabular}{llll}
\hline $\begin{array}{l}\text { Days of } \\
\text { composting }\end{array}$ & C:N & $\begin{array}{l}\text { Difference of C:N between } \\
\text { compost and initial mixture }\end{array}$ & $\begin{array}{l}\% \text { decrease over } \\
\text { initial content }\end{array}$ \\
\hline 0 & 38.10 & & \\
30 & 25.10 & 13.0 & 34.12 \\
60 & 21.19 & 16.91 & 44.38 \\
90 & 16.25 & 21.85 & 57.35 \\
\hline
\end{tabular}

is well documented ${ }^{12-14}$. Electrical conductivity is due to calcium and magnesium ions. Calcium and magnesium are released during mineralization of wastes by microorganisms. Chloride ions are reduced by $62.72 \%$ after composting than that of before composting which shows that composting is an effective means to detoxify the chloride toxicity. A sharp decrease in chloride ions shows mineralization of chlorinated compounds ${ }^{15,16}$. The calcium released during mineralization may be used to maintain the $\mathrm{pH}$ of composting material alkaline and hence free calcium is decreased.

\section{Available phosphorus and potassium}

Data regarding available phosphorus and potassium are presented in Table-2. Data reveals that their contents increased by 34.15 and $170.0 \%$ respectively at maturity compared to that of sheep dung alone before composting. Increase in content of available phosphorus and potassium during composting due to solubilization effect of heat and various acids produced is very natural ${ }^{17,18}$.

Total organic carbon, total nitrogen and $\mathrm{C}: \mathrm{N}$ ratio

Organic carbon decreased continuously with the age of compost (Table-3). In sheep dung alone before composting organic carbon was $17.17 \%$ which decreased to $12.55,8.90$ and $7.15 \%$ after 30, 60 and 90 days of composting which was $26.91,48.17$ and $58.36 \%$ decrease compared to before composting. Total nitrogen content in sheep dung alone before composting was $0.56 \%$ which decreased to $0.41 \%$ after 30 days of composting but thereafter it increased and reaches to 0.42 and $0.44 \%$ level after 60 and 90 days of composting (Table-3). Data clearly show that there was a slight change in total nitrogen content during composting and after composting its value decreased than that of sheep dung alone. Nitrogen may be utilized for microbial cell growth or lost by ammonification. Ratio of organic carbon to total nitrogen at zero days of composting, when sheep dung was mixed with leaves of Calotropis gigantea, was 38.10 which decreased by $34.12,44.38$ and $57.35 \%$ after 30,60 and 90 days of composting (Table-4). Reduced C:N ratio after composting was reported previously ${ }^{19}$. Organic carbon is being utilized by microorganisms present in compost as energy source and its reduced amount reveals decomposition of waste by microbial action $^{20}$. A portion of this carbon is assimilated by microbial cells and some part is lost as carbon dioxide $21-24$.

\section{CONCLUSION}

On the basis of findings of study it can be concluded that sheep dung and leaves of Calotropis gigentea can be composted successfully and produces nutrient rich compost.

\section{ACKNOWLEDGMENT}

Authors are highly thankful to Gujarat Vidyapith, Ahmedabad for providing financial help to conduct this experiment at Department of Microbiology through Career Oriented Programme at UG level. 


\section{REFERENCES}

1. Camplin, W.C., Baxter, A.J. and Round, G.D. Environment International, 22(1); S259 (1996)

2. Sönmez I, Kaplan M and Sönmez, S, Asian Journal of Chemistry, 19(7); 5639, (2007).

3. Bernal M. P., Albuquereque J. A., Moral R, Bioresour Technol, 99; 3372 (2008).

4. Arau'jo A.S.F., Santos V. B., Monteiro R.T.R., Brazil. Eur J Soil Biol., 44; 25 (2008).

5. Zucconi F. and De Bertoldi M, Ingegnerta Ambientale., 11; 110 (1982)

6. Xi B, Wei Z and Liu H, J. Am. Sci., 1; 34 (2005)

7. APHA, Standard methods for the examination of waste and waste water. $16^{\text {th }}$ Edition, Washington, DC. (1985)

8. Walkley A. and Black I.A., Soil Science, 34; 29 (1934)

9. Bremner J. M., Methods of Soil Analysis. Part 3-Chemical methods, ed. D.L. Sparks, 1085-1122. SSSA Inc., ASA Inc., Madison, WI, USA. (1996)

10. Olsen S.R., Cole C.V., Watanabe F.S. and Dean L.A., U.S. Department of Agriculture Circular, 939. (1954)

11. Hanway J.J. and Heidel H., lowa Agric, 57; 1 (1952).

12. Benito M, Masaguer T. O., Moliner T. O., Arrigo N. and Palmmm M, Biol.Fertil. Soils 37; 184 (2003)

13. Page T.O., Miller D.H and Keeney, (Eds).
Methods of Soil Analysis, Part 2, 2nd edn microbiological Chemical and properties. Agronomy Series 9 ROASTS SSSA, Madison, Wi. The USA. (1982)

14. Miller, F. Minimizing Odour Generation. In: Science and Engineering of Composting. Hoitink and Keener, 219-241. (1993)

15. Michel, F.C., Graeber, D., Forney, L.J. and Reddy, C.A. Biocycle, 37(3); 64 (1996)

16. Bywater, S. The Composting Association,151 (1998)

17. Chaudhuri P.S, Pal T.K, Bhattacharjee G. and Dey S. K. Tropical Ecol., 41; 107 (2000)

18. Garg P, Gupta A and Satya S. Bioresour. Technol., 97; 391 (2006)

19. Bertoldi, M. de, Vallini, G., Pera, A. and Zucconi, F. Biocycle. 2.3 (2); 4550 (1982)

20. Mondini C., Dell'Abate M.T., Leita L. and Beneditti, A., Journal of Environmental Quality, 32; 2379 (2003)

21. Cabrera M.L., Kissel D.E. and Vigil, M.F., Journal of Environmental Quality, 34(1); 75 (2005),

22. Fang M., Wong M.H. and Wong J.W.C., Water Air Soil Pollution, 126 (1-2); 1 (2001),

23. Nakasaki K., Sasaki M., Shoda M. and Kubota H., Applied Environmental Microbiology, 49; 42 (1985),

24. Fares F., Albalkhi A., Dec. J., Bruns M.A. and Bollag J.M., Journal of Environmental Quality, 34; 1392 (2005), 